Article

\title{
The Black Criminal Other as an Object of Social Control
}

\author{
Patrick Williams * and Becky Clarke \\ Sociology Department, Manchester Metropolitan University, Manchester M15 6LL, UK; r.clarke@mmu.ac.uk \\ * Correspondence: p.williams@mmu.ac.uk
}

Received: 29 September 2018; Accepted: 26 October 2018; Published: 13 November 2018

check for updates

\begin{abstract}
Throughout this paper, we contend that the 'gang' has been appropriated by the state as an ideological device that drives the hypercriminalisation of black, mixed, Asian, and other minority ethnic (BAME) communities. Drawing upon two research studies, we demonstrate how the gang is evoked to explain an array of contemporary 'crime' problems, which in turn (re)produces racialised objects to be policed. With particular reference to collective punishments, we suggest that "gang-branding" is critical to the development of guilt-producing associations that facilitate the arrest, charging, and prosecution of countless numbers of BAME people for offences they did not commit. As such, there is now an urgent need to 'take seriously' the criminalising intents of a dangerous criminology of the Other, which legitimises intrusive racist policing and surveillance, and justifies the imposition of deliberate harms upon racialised communities.
\end{abstract}

Keywords: joint enterprise; othering; gangs; (collective) punishment; racialisation

\section{Introduction}

This paper draws upon the contemporary commodification and state uses (and abuses) of the 'gang' as a resource through which to demonstrate how (re)productions of a black, mixed race, Asian, or other minority ethnic (BAME ${ }^{1}$ ) criminal serves a policing and political function. Our argument herein is threefold. First, through a brief examination of official government outputs, we highlight the criminological assumptions that support the criminalisation of racialised bodies. However, rather than providing evidence of 'racial bias' or racial disparity (Ministry of Justice 2017b), we note the otherising intents of such outputs as characteristic of an ever-increasing body of uncritical academic 'gang' research. Second, in drawing upon the insightful work of Krumer-Nevo and Sidi (2012), we reveal the process of Othering through which the lives and behaviours of racialised people become empirically objectified. Evidently, Otherisation precipitates and increasingly informs interactions between BAME people and the agents and agencies of the penal system. Throughout, we contend that it is through such moments that the racialised object to be policed and punished is produced. Within the contemporary moment, it is the wilfully vague (ab)use of the 'gang', shamelessly peddled by a dangerous 'criminology of the Other' (Garland 1996), which has served to ideologically reify the 'myth of black criminality' (Gilroy 1982). Further, the racialised gang as an object that has been incessantly mediated by vote-seeking politicians functions to legitimise the expanding penal control apparatus. In placing the contemporary construct of the racialised 'gang' within its wider historical

1 Within this paper, we adopt the use of BAME to refer to Black, Asian, and other Minority Ethnic people. Whilst we acknowledge the potential of Othering through the attribution of traits and characteristics to a widely heterogeneous group, the term is employed in many of the reports and research articles discussed throughout this paper. Where discussion concerns the particular response a reaction to a specific ethnic group/community, this will be highlighted. 
and political context, we detect the reproduction of the black folk devil, which was communicated as a threat to social order and values of 'Britishness', as those people were not 'like us'. As such, rather than responding to the contemporary concerns of interpersonal, domestic, and structural violence, we suggest that the primary function of the gang industry in England and Wales is to secure the normative boundaries of the imagined (white) society against the incursion of black and brown bodies.

\section{Excavating the Criminalised Other}

Throughout England and Wales, black, mixed race, Asian and other minority ethnic people are eight times more likely to be stopped and searched by the police (Shiner et al. 2018); they are also more likely to be arrested, charged, and found guilty in the Crown court (Ministry of Justice 2017a). Relatedly, 'BAME' people are at greater risk of receiving custodial sentences, with $26 \%$ of the prison population comprised of black, mixed race, Asian, and other minority people (Ministry of Justice 2017a). Within Young Offender Institutions, this group now comprises $44 \%$ of the population, who are incarcerated and present as an ever-ready cohort to transition to the adult estate when they become 21 years of age. There is a quantifiable reality of racial disparity within the Criminal Justice System (CJS) of England and Wales (Ministry of Justice 2017b). However, rather than being read as a national disgrace, today, such figures rarely receive public debate or discussion, being (mis)read as criminological fact. Consequently, there is a criminological, political, and community silence regarding explanations of the factors that drive the underpolicing of 'white' people and the overpolicing of black, mixed race, Asian, and other minority ethnic people. That BAME people are perennially overrepresented in the 'counts', 'percentages', 'proportions of', and 'totals' of the Ministry of Justice (MOJ) sponsored 'Statistics on Race in the Criminal Justice System' (RCJS) serves to communicate and reaffirm a public consciousness in which non-white people are disproportionately engaged with and predisposed to criminality (Gilroy 1982). For Gutsmore writing some 30 years ago, there has long existed a 'special' social category attributed to young black men, which serves to legitimise the development and application of increasingly complex and punishing penal apparatus (Gutzmore 1983, p. 26). Consequently, the stereotyping of young black men as 'dangerous, violent and volatile' is a longstanding trope that is ingrained in the minds of many in our society (Angiolini 2017, p. 87).

Central to our arguments here is the silence that accompanies the publication of RCJS, which illustrates the accomplishment of an ideological construction of black and brown people as exceptionally crime-prone. Furthermore, it is the durability of this ideology that serves to rationalise and legitimise the evocation of an array of powerful penal tools and apparatus that are designed to regulate black and brown bodies. However, an informed reading of the above outputs confirms that the race-crime nexus is unrelated to crime, however defined, but rather reflects a catascopic view of the 'institutional framework of [the] criminal justice' (Hulsman 1986, p. 300). RCJS then is an amalgam of inputs and outputs from an increasingly complex fragmented and demoralised criminal justice (CJ) 'system'. The figures represent a synthesis of the monitoring information extracted from the recording and assessment processes of over 300 organisations and institutions, representing a partial view of the practices, policies, and directives from the United Kingdom (UK)'s Home Office and Ministry of Justice departments (Cavadino and Dignan 2015). From the outset then, and with particular reference to the discipline of Criminology, such outputs are an exemplar in Othering, producing raced objects to be policed (Krumer-Nevo and Sidi 2012; Owusu-Bempah 2017). Throughout the following, Othering refers to the 'process of attaching moral codes of inferiority to difference', and is emerging as a critical discursive tool for understanding discrimination(s) imposed upon and used against individuals and/or groups based on their belonging to racialised and othered, marginalised populations (Krumer-Nevo and Sidi 2012, pp. 299-300; Spalek 2008).

Along with Krumer-Nevo and Sidi (2012), we accept that particular administrative research and analytical strategies are intrinsic to the production and presentation of racialised groups as (an)other (Clarke et al. 2017; Williams 2017; Garland 1996, 2001). 
Krumer-Nevo and Sidi (2012, p. 300) noted the objectification of the research participant through the 'subjugation of their common humanity' where administrative social research ignores or, of more concern, resists the inclusion of personal perspectives and subjectivities. It is the objectification of the 'offender', or research subject, which drives the imposition of seemingly infallible and racialised inferiority traits. The problematised characteristics of black culture that are associated with those who are othered drives criminalisation. Second, Krumer-Nevo and Sidi noted that the sociological production of the Other, decontextualisation, preserves a vagueness wherein the presence and behaviours of black and brown bodies are 'abstracted from the context within which the behaviour occurs'. Decontextualisation portrays 'actions, behaviours and responses' as having no reason or rationality and are consequently reframed as deterministic, fixed pathological traits of the individual. Such administrative approaches are central to the continuities of race-crime debates stretching from the 1970s to the present day (Amos et al. 1982). Where conceptualisations either neglect the significance of (colonial) history, thus serving to de-historicise the subject by situating the object of study within the dominant socio-political moment of the present, or form deterministic explanations of this history as a further causal factor in the race-crime nexus. The effect is to ignore, negate, and abstract the 'personal individual history of the research participants' (Krumer-Nevo and Sidi 2012, p. 300), promoting the production and (re)presentation of black and brown Others as new(s), located at the centre of mediated stories, seemingly devoid of rationality and essentialised as 'dangerous' and threatening to our way of life (Aliverti 2012). Crucially, othering publications reflect deauthorisation, producing perspectives that are external to the research participants' lived realities, essentially reducing the participant to objects and thus concealing and obscuring the ways in which the objects of study are the products of politically and officially sanctioned interpretations (Centre for Social Justice 2009; Ministry of Justice 2017a). These interpretations become mainstreamed within the deauthorised research product; they are then endowed with an incontrovertible authority and become 'fact', and thus insulated from counterchallenge and critique. The above consequently demands that we see through the otherising tendencies that are integral to many contemporary research products and outputs that drive official and popularised constructs and narratives of black, mixed race, Asian, and other minority ethnic communities. We will respond to what is exposed here, and show that once framed from this position, the 'objects' emerge to the fore, revealing the control mechanisms, pain infliction, and suffering endured by racialised individuals and communities.

\section{Research Methodology}

Within the above, we detect the limits of criminologies instituted in service of the state to appreciate the 'personal troubles' experienced and endured by black and brown bodies (Garland 1996; Hillyard et al. 2004; Hulsman 1986). Further, we note the above otherising mechanisms that conceal the harmful effects of contemporary criminal justice control approaches. Within the remainder of this paper, we move to dissect the hegemonic intersections of Criminology, control agencies, and political actors in driving up racial disparities in the pursuit of criminal injustice. To this end, we adopt the contemporary, yet historically situated, production of the violent gang as a resource (Katz and Jackson-Jacobs 2004) through which to illustrate the durability of the racialised 'folk devil', which is used to legitimise the enactment of intrusive, powerful, and unaccountable criminal justice devices.

In relation to the above, we are guided by the findings to emerge from two research studies undertaken by the authors. The first study, entitled 'Dangerous Associations: Joint Enterprise, Gangs, and Racism' was delivered on behalf of the Centre for Crime and Justice Studies (Williams and Clarke 2016). Joint enterprise (JE) is a doctrine of common law that permits the prosecution of more than one person for the same offence. The doctrine can apply where suspects may have played different roles, and where a suspect was not in the proximity of the offence committed. Intrinsic to the application of the doctrine is the principle of 'common purpose' where it is alleged that individuals have planned to commit crime(s) together. Where such a 'common purpose' is 
demonstrable, peripherally associated individuals, or 'secondary parties', may also be held liable for the crime(s) committed by one member of the group, even though they may not have participated in or intended for the crime(s) to be committed (Squires 2016; Crewe et al. 2015). ${ }^{2}$ The study adopted a semi-structured questionnaire survey of 241 prisoners who were serving lengthy custodial sentences for JE offences with the central aim of considering the relationship between the (re)emergent use of JE as a collective punishment, and the prevalent discourse of the gang as politically instituted (and sanctioned) to respond to reported levels of serious violence. The second study, entitled 'Being Matrixed: The (Over)policing of Gang Suspects in London', was commissioned by the StopWatch charity with the central objective of foregrounding the stories of individuals who had been registered to the Trident Police Gang Matrix in London (Stopwatch 2018). The method demanded in-depth qualitative interviews, or what we refer to as research 'conversations', in order to enable the telling of recollections, personal stories, and reflections of being policed (Williams 2017).

The priority for both these studies was to enable individual experiences and events to be placed within their wider context. Whilst being matrixed-that is, being registered to a police 'gangs' database or collectively punished - was at the heart of these studies, foregrounding the perceptions of respondents rather than reliance upon police and / or wider CJ data as constructs of reality presents a significantly personalised perspective of being policed and punished. These minority perspectives are often silenced and obscured (Clarke et al. 2017; Phillips and Bowling 2003). Through the responses and narratives of those who participated in the research, it is possible to detect the pervasive and unrelenting array of the $\mathrm{CJ}$ apparatus to which increasing numbers of minority ethnic youth are subject. What emerges as apparent is the multifaceted and concealed function of the gang industry, which drives the criminalisation of minority ethnic groups for their presence and proximity to imagined notions of criminality.

\section{Criminologies of the Other}

For Spalek (2008, p. 4), the discipline of Criminology is intrinsically implicated in the construction of racial hierarchies, which 'institutionalise oppression and discrimination, through the production of Others'. The research, political, and social value of the Other can be detected in the appropriation of the concept in various academic disciplines representing a range of methods of analysis and increasingly diverse forms of social inquiry. Criminological identifiers of the Other are contingent upon the cultural and social processes that are linked to the dominant context-specific themes of any given society. The social identification, categorisation, and 'ontologisation' of the Other (Ahmed 2000) marks the imagined boundaries of the community, and hence the methods for inclusion (Ajzenstadt and Shapira 2012; Anderson 2013). Consequently, those who reside outside of the moral boundaries and 'regimes of power' are 'devalued, and their voices and perspectives are largely suppressed' (Spalek 2008, p. 4). In this regard, Criminology as a discipline can be implicated as intrinsic to an endeavour that empirically produces the criminalised Other to embody a wide array of contemporary State-defined crime problems. Garland (1996, p. 461) notes the prevalence of a:

[C]riminology of the other ... of the threatening outcast, the fear-some stranger, the excluded and the embittered. [It] is concerned to demonize the criminal, to excite popular fears and hostilities, and to promote support for state punishment.

Whilst racialising constructions of black people as criminal can be detected within the early theorisation of Cesare Lombroso (Phillips and Bowling 2003; Spalek 2008), recent academic conceptualisations can be confined to the race-crime debates of the early 1980s. Here, the incursion of the academy into the political debates concerning the relationship and explanations of crime and

2 For additional information, see guidance provided by the Crown Prosecution Service. https://www.cps.gov.uk/legalguidance/secondary-liability-charging-decisions-principals-and-accessories. 
minority ethnic people within the UK are notably found in Lea and Young (1984), 'What is to be done about Law and Order', and specifically the chapter related to the 'race and crime' nexus. Presented as an rebuttal of criticisms put forward by Gilroy et al. in a series of papers relating to 'The Myth of Black Criminality' (Gilroy 1982), the fore of this debate was the presentation of official police statistics, which attested to an overrepresentation of black people as involved in the offence of street robbery. It is noteworthy that this debate was prefaced by Hall et al. (1978), whose study chronicled the emergence of a moral panic surrounding the emergence of 'black crime'. For our purposes, 'Policing the Crisis' documents the State's complicity in the production and racialisation of 'mugging' as a new crime, highlighting the processes through which race is constructed as a social and political relation. For Hall et al., the 'black mugger' was evoked as a discursive device to explain (away) a series of 'hegemonic' crises marked by a significant economic recession following the oil crisis of the 1970s and the breakdown of the post-war consensus. Further, Hall et al. noted a crisis of (national) identity where the visible presence of the British-born black and brown children of the 'Windrush' generation ${ }^{3}$ marked a significant breach of the normative boundaries of 1970s British society (Williams 2017). The almost prophetic analysis of Hall et al. back in 1978 is significant where the black object as migrant becomes recast as the black criminal Other as a device to explain the myriad of problems affecting British society. To illustrate, Lea and Young's analysis of official statistics reported that $36 \%$ of the victims of 'robbery and violent theft' in London reported that the offence was perpetrated by 'coloureds' (Lea and Young 1984, p. 140). Such figures were indicative of a 'reality' of black crime, which was something to be 'taken seriously' by control agencies and politicians alike. Contrastingly, for Gilroy et al., the production of black crime was illustrative of the state construction of 'alien violence' as an important and powerful discursive tool in the hands of 'politicians and police officers'. It is against this backdrop that the both political and importantly academic debate of 'alien violence' serves to assuage crises and legitimises the growth and use of law and order apparatus, including military policing, through 'a racist appeal to the British nation [which was] integral to maintaining popular support for the government in crisis conditions' (Gilroy 1982, p. 47):

The imagery of alien violence and criminality personified in the 'mugger' and the 'illegal' immigrant has become an important card in the hands of politicians and police officers whose authority is undermined by the political fluctuations of the crisis. For them, as for many working-class Britons, the irresolvable difference between themselves and the undesired immigrants is clearly expressed in the latter's culture of criminality and inbred inability to cope with that highest achievement of civilization—-the rule of law (Gilroy 1982, p. 48).

Lea and Young's ire then is invoked by the criticism of their theorisation in particular, and similar to the wider critique of a (white) sociology of race relations research (Amos et al. 1982; Lawrence 2014). Herein lies the predominance of criminological-induced 'false stereotypes' that (re)produced and maintained the race and crime nexus. The emergence of 'black crime' and 'alien violence' becomes abstracted from and unrelated to community (over)policing and the process of criminalisation, thereby reducing 'black crime' as an innate, subcultural feature of black people and black communities. Gilroy (1982, p. 52) reflecting on Lea and Young's 'startling ignorance':

[t]hey view West Indian life as characterised by pathological family relations and a high degree of generational conflict, but these are not presented as the sole source of black criminality. Discrimination, disadvantage, and economic alienation clash with inappropriate aspirations derived from the internalisation of 'British values' (sic) and this also generates the 'propensity' to crime'.

3 'Windrush' is a collective term used to describe the Caribbean migrants who arrived in Britain following the Second World War. Windrush is a direct reference to the ship, SS Empire Windrush, which arrived into Tilbury Docks, Essex from Jamaica on 23 June 1948. 
Located within the above, we detect the persistence of analytical frameworks that attribute the tensions in the processes of assimilation and integration into British society to the black post-war migrant as an explanation for the increased likelihood of black peoples' involvement with crime. Rather than police community interactions being relevant to the process of criminalisation, for Lea and Young (1984, p. 128):

A more plausible explanation might be to suggest that what was happening in the 1970s, and which was marginally reflected in police evidence to the Select Committee in 1971, was the failure of the Race Relations legislation of the 1960s to lay the basis for racial integration. In this context, the growth of the second generation of young black British, coming through the school system and facing ... the dual process of assimilation and rejection, resulted in the growth in street crime.

Remarkably, and of particular relevance to the contemporary construction of BAME people as predisposed to 'gang-enabled' violence, the above propositions marked a dangerous conceptual shift in police and academic discourses of migrants as 'at risk' of criminal behaviour as a feature of their location within anomic environments and seemingly culturally ill-equipped to navigate complex societies. Such criminological explanations, which retain their focus on the deterministic and nihilistic features of racialised youth, exclude a serious examination of the harmful and unwarranted incursion of the police into the lives of these young people. As we have argued elsewhere, to disregard the processes by which young people become criminalised simplistically serves to reaffirm explanations that locate offending behaviour at the individual level (Poynting et al. (2018)), echoing and reaffirming police constructions and versions of the reality of crime. With due regard to the race-crime nexus as discussed above, there are remarkable parallels when framed within the present context of an austerity-damaged and Brexiting British society and the conceptualisation of the racialised gang, echoed across political, mediated, and academic contexts.

Over a century of international academic research on 'gangs' has failed to provide any reliable causal evidence of the relationship between gangs and (violent) crime (Katz and Jackson-Jacobs 2004). Instead, academic endeavours in this area have focussed attention on defining gangs and describing the behaviours of those who are so defined by an increasing array of state actors, led by the police. Much of this work mediates a police construct of gang-enabled crime, serving to 'rationalise policing reconstructions of reality' (Keith 1993). In light of the contemporary panic concerning levels of serious violence, the extent to which this body of work has offered any meaningful and empirically sound explanation for the enduring overrepresentation of racialised communities within the groups defined as 'gangs' is now worthy of serious challenge. The gang is predominantly racialised to young black men, with $78 \%$ of the Trident matrix comprised of young black men. Within the UK context, the racial composition of the 'gang' has been presented as a reflection of the racial composition of the areas wherein crime disproportionately occurs (Bennett and Holloway 2004; Aldridge and Medina 2007). For others, economic marginalisation, where systemic factors conspire to affect the life chances of those who reside in racialised communities, drives a 'reality' of criminality (Pitts 2007). Where academics have engaged with the racialisation of the gang, they are racialised within the constraints of the neoliberal global economy, where it is argued that consequent anomic strain due to their exclusion from the labour market drives young people towards lives shaped by (sub)cultural values and the lifestyle of a pathological 'road' culture (Joseph and Gunter 2011). Significantly, throughout such positions, there endures the reality of the gang, whether evoked explicitly or not, inferring a distinct cultural problem within minority ethnic communities and necessitating a distinct criminal justice response.

\section{Now You See Them, Now You Don't-Gang Politricks}

Whilst the 'gang' represents the latest in a long line of negative social constructions of black criminality (Gilroy 1982; Keith 1993), the intensification of the political and academic narrative of the 'gang' reached its apex following the disturbances in England in August 2011. At that time, and 
despite the evidence that emerged challenging these assumptions (Travis 2011), the media, politicians, think tanks, and academics were quick to evoke the already established views of the 'gang problem' (Home Office 2007; Centre for Social Justice 2009) as a driving force behind the riots. This policy and media rhetoric blamed a criminal black subculture, imbued by pathological, anti-authority attitudes (Cameron 2011). Whilst such explanations were challenged, and the Government themselves acknowledged the error in this assumption (HM Government 2011), the Ending Gangs and Youth Violence policy was set, with 'gangs' established as the driving force behind serious youth violence. However, findings to emerge from a number of recent analyses of official CJ data, where police recorded data on gangs and youth violence has been reviewed, instead points to a less linear relationship between race, 'gangs', and serious violence, which demands an alternative theorisation. In 2012, Clarke et al. (2012) completed an independent 'problem profile' (a feature of the Home Office Ending Gangs and Youth Violence (EGYV) policy launched in 2011), to ascertain the relationship between gangs and serious youth violence in Manchester (HM Government 2011). The findings revealed that in central Manchester at the point of analysis, these two phenomenon, as constructed by the police and their partners, were largely unrelated. Police-recorded incidents of serious youth violence were overwhelmingly perpetrated by white people ( $76 \%$ of the sample), whilst BAME people, and in particular young black men, were more likely to be identified as 'gang-involved' ( $89 \%$ of those registered as 'gang nominals') (Clarke et al. 2012). Mapping further revealed that not only was the EGYV policy conflating different 'crime' problems, but also that these were largely located in different communities and areas. The analytical profile confirmed that whilst the neighbourhoods highlighted for both 'serious youth violence' and 'gangs' were those that were high on measures of socio-economic disadvantage, the key distinction between them was the ethnic profile of the residents. It was in those communities that were racialised as black that the 'gang'-flagged individuals were located, and subsequently, the majority of government funding and activity deriving from the EGYV policy was targeted in this direction.

Further analysis commissioned in 2015 from the London Mayor's Office for Policy and Analysis (MOPAC) confirmed a similar gang violence disconnect (Williams and Clarke 2016), with this analysis followed up by a report for the London Assembly Police and Crime Committee (2016) which recognised that:

[S]erious youth violence in London is often considered a 'gang issue'. [T] Police] data shows that the gang element was identified in a relatively small amount of serious youth violence: just under $5 \%$ in 2015-2016. This figure has been fairly consistent since 2011-2012 (London Assembly Police and Crime Committee LAPCC, p. 3).

Significant here is the notion of politricks. We use the term here to characterise the use of concealed and underhanded methods to achieve a political end. While there is strong evidence to negate the significance of gangs, the government still moved to initiate a 'war against gangs' (Scott 2018). Consequently, the policy and practice focus of 'fighting gangs' has evidently resulted in the problem of serious violence remaining largely untouched. Given that these two 'crime' problems are unrelated in the ways that politicians and criminal justice practitioners imagine, how do we understand the widespread and enduring focus on racialised communities? Before responding to this question, it is noteworthy that today, such politricks can be detected in the ambiguation of the 'gang' with the emergent crime concerns of 'county lines', modern-day slavery, and 'child (sexual) exploitation' (Harding 2019). Whilst such crime problems long precipitate the racialised gang, the foci for academic attention and new black objects to be policed are seemingly ready-produced when Richard Tucker, the Detective Chief Superintendent of Newham in London stated that ' $[t]$ hings are horrific. Gangs are more dangerous than paedophiles' (Long 2018). 


\section{Punishing the Non-Violent Racialised Gang}

“They think they know me. They don't know me. That's what these police officers go off. They think they know you because they see things on paper and they think they can make a judgement. It's like, 'No, you can't search me. I am not going to bow down to you because you found out I have been in trouble with the police. I haven't got any drugs'"' [Paul $]^{4}$.

The failure to subject the construct of the racialised 'gang' to serious critique serves to silence the disproportionate and significant harms that emerge for young minority ethnic people from a range of contemporary gang policing and punishment strategies. In accepting the 'reality' of the gang, but in failing to explain the significance of race as a factor in the perpetration of youth violence, the discipline of criminology echoes and aligns itself as complicit in the perennial racialisation of crime towards black, mixed race, Asian, and other minority ethnic groups. For the young black men who contributed to the Being Matrixed study, there was a historically contingent and pervasive sense of being policed that enveloped their everyday community interactions and policed encounters. Remarkably, a consistent narrative converged to highlight the significantly intrusive forms of policing and surveillance that they endured. For example, respondents were asked to reflect upon being stopped and searched, and in doing so, were asked to recollect, 'How many times have you been stopped and searched?' Consistently, all reported unbelievably high levels of being stopped and searched, with many of these encounters confrontational and at times accompanied by police violence:

“Too many to count. I could not possibly count. I've been stopped and searched, probably, I don't know, a couple of hundred times, probably, I don't know. Used to get it regular, I've got a conviction because I was stopped and searched three times in one day. Now if you're stopped and searched three times in one day, how are you going to feel? But a lot of times you get stopped and searched, you've taken the fucking piss, I flipped. I got done for public disorder and I was thinking, I haven't actually done nothing, you have stopped me three times in one day and obviously I'm going to be peed off, I'm a teenager as well at the time. So, I found it hard to hold my tongue and yes, I got a conviction for public disorder, I flipped, and I was thinking, 'Well, I was actually minding my own business. You saw me, you're pestering me, you've done it three times, what else do you expect me to do. You've actually arrested me, and I've got that conviction on my record, but I'm thinking, well in actual fact, I actually hadn't done anything wrong. You've stopped and searched me three times'" [Ricky].

For Ricky, there is no predisposition driving the perpetration of 'his' public order offence, other than the indignity of being overpoliced. He concedes flipping, being unable to 'hold his tongue'; however, it is the criminogenic nature of police community relations here that marks the above quotation. In moving to understand this further, the work of Haining and Law (2007) examined the relationships between police-defined 'high-intensity crime areas' (HIAs), which included the neighbourhoods that police officers perceived as requiring a distinct policing approach, and empirically-based HIAs, where recorded crime mapped where the distinct crime problems existed. Whilst the authors recognised the potential bias in both sources of data, they found that the bivariate correlation between mapped HIAs, perceived versus empirical, was low (less than 0.01), demanding explanation. The authors reflect that '[p]olice perceptions [of high crime areas] may be influenced by particular past experiences and attitudes as well as what is or is not remembered.' Further analysis revealed a significant underlying covariate: the ethnic composition of the area. It was racialised locations, characterised by 'high ethnic heterogeneity', that were more likely to be viewed by the police as HIAs, and such views persisted despite police-recorded crime, which indicated that high-intensity 
crimes were located elsewhere. Of equal importance here was the process by which the police who contributed to this study were prompted to recollect high-crime areas. Guided by a 'force performance team', officers were asked to locate the areas that were 'most difficult to police'. In assisting officers, the performance team 'prompts' highlighted the persistent institutional effects of memoried racialisation which, despite police evidence, diverted attention away from high-crime areas towards locations inhabited by black and brown people. The prompts that were used indicated that high-crime areas were equated with 'gang culture', areas imagined with 'a high propensity to violence', 'a serious drugs problem', 'transient populations', and 'hostile to the police'. The process of determining what and who is the 'crime problem' is tautological; it both constructs and conjures up who is or is not, or what areas are or are not difficult to police. The Haining et al. study demonstrated the ideologically given race crime nexus that has been imposed upon minority ethnic communities. Such attributions reflect police constructions that emerge from those everyday encounters and interactions with black, mixed race, Asian, and other minority ethnic people and communities, marking what Owusu-Bempah (2017) conceptualised as a disdain for minority ethnic communities. Furthermore, such ideas have now become empirically embedded or hardwired into the CJS of England and Wales, irrespective of the reality or actuality of crime.

\section{Racism(s) as Hardwired: Gangs, Risk-Talk, and Guilt-Producing}

"I have been branded as [a] gang member because I have lived in the area of gang crime and drugs and have associated with people who have been involved in certain activities. I think that is unfair and not just in my situation, it's in every situation. People shouldn't be branded because of their surroundings, their religion, or what they do. I should be able to have friends that may do bad things, but the police should know or be able to understand that I am not involved in that and separate it. They should be able to know that there are certain Muslims who try to kill in the name of Allah, but there are certain Muslims who believe that is wrong and go against all of that. It's two separate things, and that is why all of this gang-branding and all of that shit is mad. That's why the police don't understand, and that is what they need to understand" [Stephen].

Above, we highlighted the police attribution of negated criminalised associations upon minority ethnic communities, despite the high incidence of violence recorded in areas of low ethnic heterogeneity, or put more clearly, in 'white' communities. Through our research into the doctrine of joint enterprise, we explicitly detected the attribution of the 'gang' as a legal prosecution tool effecting harm upon those who inhabit racialised communities. The isolation of the gang label to minority ethnic communities fulfils a stigmatising function whereby the inhabitants are conspicuously imbued with criminogenic intention through their interactions and associations with police-defined gang suspects (Alexander 2008). Writing on the re-emergence of JE, Squires (2016) astutely observed that JE becomes re-enacted due to the pitiful detection and conviction rates of the police in apprehending the perpetrators of high-profile fatal shooting incidents. Related to this, Lord Falconer unambiguously denoted the virtue of JE collective punishments where:

The message that the law is sending out is that we are very willing to see people convicted if they are a part of gang violence-and that violence ends in somebody's death. Is it unfair? Well, what you've got to decide is not, 'Does the system lead to people being wrongly convicted?' I think the real question is: 'Do you want a law as draconian as our law is, which says juries can convict even if you are quite a peripheral member of the gang [that] killed?' And I think broadly the view of reasonable people is that you probably do need a quite draconian law in that respect (BBC Radio 4 Today Programme 2010).

Importantly, the enactment of such powers emerged in response to mediated concerns of a reported increase in the levels of serious violence and particular firearms offences (Clarke et al. 2012). Again, for police and other political actors, violence is (mis)placed as a particular feature of BAME 
young people and communities. For Stephen above, the gang "branding" is unfair; it was stigmatically imposed upon him because of his "surroundings", "religion", "friends" or "associations". It is here that strategies of criminal regulation and deterrent-based crime control connoted under the guise of 'ending gangs' or the 'war against gangs' is marked by a now decades-old 'hostile environment' created within those racialised communities that are stigmatised as suspicious. To demonstrate how such processes develop through the increased use of analytical tools, a recent Home Office-funded report entitled 'Social Network Analysis of an Urban Street Gang Using Police Intelligence Data' by Gunnell et al. (2016) highlighted the 'gang'-producing tendencies that were intrinsic to police attempts to build and regulate 'networks' of gang nominals. Based upon the Greater Manchester Police 'intelligence' of five 'gang members', Gunnell et al. produced an analytical webbed 'urban street gang' network of 137 nodes or nominals. What is significant to their findings is that whilst not all of the 'individuals' identified in the 'web' were gang members, they were deemed "at risk of being involved in gang activity or at risk of harm through being connected to the gang" (Gunnell et al. 2016, p. 12). Of further relevance, of the 137 individuals isolated through the analysis, $115(84 \%)$ were connected to the 'gang members' not through criminal, but 'other social links' referred to as 'family', 'friendship', and 'romantic' links. The report acknowledged that despite having no 'criminal', 'drugs', or 'gang' links, they still received police (and subsequently academic) attention due to their proximity to the (social) network of the five police-defined 'gang' members. Again, for Stephen above, it is not his criminal behaviour that initiated his police interactions, surveillance, and/or overpolicing, but rather his proximity to high ethnic heterogeneous communities. Close proximity to police-defined and memoried problem areas - to be resident or associated within black and brown spaces-blemishes and contaminates the self, cyclically affirming to the police the imposed identifier of the 'risked' (Tyler 2018; Williams 2017). Gang-branding and being matrixed contemporaneously serves to amplify and legitimise the practice of empirically producing and responding to risks, which whilst racialised, is now algorithmically hardwired and concealed into CJ practices and processes. Consequently, and reminiscent of the control mechanisms of the colonial subject, it is today within black and brown communities that 'risk management' apparatus and tools of social control and surveillance are enacted and deployed (Moore 2014).

"I remember there was a time when I was with my brothers and sisters and we were at the bus stop and, basically, I think I was about 15 years old and I was given a condition that I wasn't allowed to go out [in public] without anyone over the age of 18. You weren't allowed to go out with ${ }^{5}$ Yes, so, I can't go out by myself, basically. So, I have to get someone to do everything for me. I was at the bus stop and I was supposed to be at school, but I was with some people from my school and we were going to [area name]. So we were waiting at the bus stop. There was a person I noticed at the bus stop and he kept looking at me, but I didn't really realise who he was at the time. Then, afterwards, I started to see him taking out something, like a phone kind of thing, but it was like... I wouldn't call it a phone, but it was like some sort of ... I would say, a walkie talkie kind of thing but a smaller version, and then I realised his face and I was like, 'That's a police officer', but I was like, 'He can't do anything because he's off duty.' So, we all got on the bus. As the bus was moving, we were going towards [area name], the next thing you know, two police cars, they came and they boxed in the bus. [Laughter]. Can you believe that? I was 15 at the time and they boxed in the bus just because I'm out without someone over the age of 18 , just because of that condition. That's something you should do when someone has a weapon on them. They boxed in the bus and they took me off. The officers came on the bus, all the way up to the top and they took me off and then they took me to the police station" [Dean]. 
"[I] remember a time, I think I was eight or nine, a year later or something, Year 9 or Year 10-that's when stop and searches ... I was getting stopped every week. Without a doubt, I'd get stopped all the time ... It was weird, man. Starting to get stopped and searched all the time to the point where it became a joke. It was just a normal thing like putting on your clothes. You knew you were getting stopped and searched ... [I]t became so normal, it felt like I knew what was going on. Everyone around me was getting stopped and searched daily. There was no one around me that wasn't in a sense. So, I just thought, 'Yeah, it's just a thing where they're just stopping young black kids'" [Andrew].

Within 'Dangerous Associations: Joint Enterprise, Gangs and Racism' (Williams and Clarke 2016), we found that $79 \%$ of minority ethnic respondents reported that 'gang talk' (Hallsworth and Young 2008) was evoked in the prosecution of their court case against 39\% of white respondents. The simplistic attribution of the 'gang' label conspired to punish secondary parties, those on the periphery, regardless of whether or not those individuals were 'at the scene' or intended for the offence to be committed. For Alexander (2008), the evocation of the 'gang' as a resource serves as a potent signifier in the process of criminalising non-criminal behaviours. Through this lens, the police-defined 'gang' and the distinct range of associated policing tools and tactics in targeted communities becomes a rich resource for prosecutors in the courtroom. An uncompromising political rhetoric of the 'gang' bolsters these policing and prosecution practices, further amplifying political calls for a distinct and punitive response (Hall et al. 1978; Poynting et al. 2018). Tellingly, of those who noted the prosecution's use of gang talk, white prisoners were nearly twice as likely to report that 'no evidence' was brought to infer their gang associations (32\%). Conversely, this figure reduces to $17 \%$ for black, mixed race, Asian, and other minority ethnic respondents, highlighting the surveillance, situated and ever-ready evidence gathering and guilt-producing devices within racialised communities that are stigmatised as gang-affected. The hegemonically communicated narrative of the racialised criminal Other, then, connected to criminologically-sanctioned products, is now upon a firm ideological foundation from which politicians, police, and prosecution teams signal (dog-whistle) to juries the public consciousness of minority ethnic people as the criminal Other. For Garry:

"The thing [that] pisses me off is that they have the power to do stuff, extra stuff, and their power derives from intelligence. You can ask them, 'What's the intelligence?' They'll say they're not allowed to tell you. 'We're not allowed to tell you.' Now, your intelligence is not a proven piece of information. Intelligence that you might have got from a grass, you might have got from someone that just dislikes other people, they're just chatting shit. You could have got it from anywhere. It's not proven in court. So, why is it then allowing you the powers to come to oppress me with, you know what I mean? You're oppressing me with power that you shouldn't even have" [Garry].

The overrepresentation of black, mixed race, Asian, and other minority ethnic people demands an urgent need to 'take seriously' the racialisation of crime and offending behaviour across England and Wales. The disproportionate numbers of innocent BAME people locked away in the damaging environment of young offender institutions and prisons due to convictions through JE collective punishments is a national scandal. The increasing number of BAME people who have lost their lives whilst in the 'arms of the state' (Scraton and Chadwick 1987) is a national disgrace. Along with Garry above, contemporary gang policing and $\mathrm{CJ}$ practice is oppressive, serving to curtail the social and economic opportunities that are critical in augmenting a sense of belonging and reaffirming the race and gang nexus (Williams 2015). Encouragingly, there is an emerging body of interventionist critical social research driven primarily by activists and campaign organisations as a counternarrative to the othering intents of the aforementioned dangerous criminology (Bridges 2015; Scott 2018, see also Institute for Race Relations and Inquest). For too long, the discipline of Criminology has remained silent and subservient to the dominant police constructions and narratives of race and crime connections. Whilst there is an urgency, we are optimistic that the development of this 'criminology from below' 
will move to 'rehumanise the Other' (Clarke et al. 2017; Scott 2013) and expose and challenge the harms of racialised criminalisation (Amnesty International 2018; Clarke et al. 2017).

\section{Conclusions}

What we have sought to do in this paper is begin a process of redress in relation to the harmful Othering that results from a number of criminal justice practices, specifically the policing and collective punishments that are disproportionately targeted and embedded within BAME communities. In critiquing the dominant official and academic sources and debates that seek to understand racial disparity or differential treatment in outcomes for groups according to their ethnicity, we suggest the need for a space for alternative analysis and explanations. Inspired by Krumer-Nevo and Sidi's framework (2012), we demonstrate the significance of research approaches and analysis that enable the re-contextualisation, re-historicisation, and re-authorisation of debates surrounding the overpolicing and punishment of the racialised Other. By foregrounding the personal perspective of those who are the objects of such practices, and subjecting the hegemonic narratives to critique, the focus appropriately turns to the role of control agencies and a dangerous Criminology that deliberately drives the criminalisation and punishment of the black Other. The evidence examined here confirms that there is no ontological value to the racialised gang, and therefore, those police and policy responses to the problem of serious violent crime that are framed through this analytically useless construct will never prevent violence and its concomitant harms. Relatedly analysis published recently of the causal factors in weapon-carrying and violent harm points to the significance of new criminogenic factors, including distrust of the police (Brennan 2018). The evidence discussed here affirms that politicians, control agencies, media, and academics must be held accountable for their role in producing crime and harm. This is a wakeup call to the discipline of criminology and the proponents of Dangerous Criminology to 'take seriously' the processes by which people become both criminalised and affected by criminal justice harms.

Author Contributions: Both authors contributed equally at all stages.

Funding: The 'Dangerous Associations: Joint Enterprise, Gangs and Racism' study was funded by Barrow Cadbury Trust and 'Being Matrixed: the (over)policing of gang suspects in London' was funded by grants awarded to StopWatch by the Open Society Foundation and the Esmée Fairbairn Foundation.

Conflicts of Interest: The authors declare no conflict of interest.

\section{References}

Ahmed, Sara. 2000. Strange Encounters: Embodied Others in Post-Coloniality. London: Routledge.

Ajzenstadt, Mimi, and Assaf Shapira. 2012. The socio-legal construction of otherness under a neo-liberal regime. British Journal of Criminology 52: 685-704. [CrossRef]

Alexander, Claire. 2008. 'Re-Thinking “Gangs". London: Runnymede Trust. Available online: http://www. runnymedetrust.org/uploads/publications/pdfs/RethinkingGangs-2008.pdf (accessed on 29 November 2013).

Aldridge, Judith, and Juan Medina. 2007. Youth Gangs in an English City: Social Exclusion, Drugs and Violence. Research Report ESRC RES-000-23-0615. Swindon: ESRC.

Aliverti, Ana. 2012. Making people criminal: The role of the criminal law in immigration enforcement. Theoretical Criminology 16: 417-34. [CrossRef]

Amnesty International. 2018. Trapped in the Gangs Matrix. London: Amnesty International. Available online: https:/ / www.amnesty.org.uk/london-trident-gangs-matrix-metropolitan-police (accessed on 5 May 2018).

Amos, Val, Paul Gilroy, and Errol Lawrence. 1982. White Sociology, Black Struggle. In Rethinking Social Inequality. Edited by David Robbins. Aldershot: Gower Publishing Company Ltd.

Anderson, Bridget. 2013. Us \& Them: The Dangerous Politics of Immigration Control. Oxford: Oxford University Press. Angiolini, Elish. 2017. Report of the Independent Review of Deaths and Serious Incidents in Police Custody. London: HM Government.

BBC Radio 4 Today Programme, and (British Broadcasting Corporation, London, UK). 2010. Lord Falconer Interview. September 8. 
Bennett, Trevor, and Katie Holloway. 2004. Gang Membership, Drugs and Crime in the UK. British Journal of Criminology 44: 305-23. [CrossRef]

Brennan, Iain. 2018. Weapon-Carrying and the Reduction of Violent Harm. British Journal of Criminology. Available online: https: / / doi.org/10.1093/bjc/azy032 (accessed on 15 August 2018).

Bridges, Lee. 2015. The Met Gangs Matrix: Institutional Racism in Action. London: Institute of Race Relations. Available online: www.irr.org.uk/news/the-met-gangs-matrix-institutional-racism-in-action (accessed on 29 June 2014).

Cameron, David. 2011. “UK Riots: Text of David Cameron's Address to the Commons," quoted in The Daily Telegraph, August 11. Available online: www.telegraph.co.uk/news/uknews/crime/8695272/UK-riots-textof-David-Camerons-address-to-Commons.html (accessed on 3 September 2012).

Cavadino, Michael, and James Dignan. 2015. The Penal System: An Introduction, 3rd ed. Thousand Oaks: SAGE Publications Ltd., p. 110.

Centre for Social Justice. 2009. Dying to Belong: An In-depth Review of Street Gangs in Britain. London: Greycoat Place.

Clarke, Becky, Charlene Crossley, and Patrick Williams. 2012. Gang and Youth Violence in Manchester City: A Partnership Problem Profile. Unpublished report. Manchester: Manchester City Violent Gangs Board.

Clarke, Becky, Kathryn Chadwick, and Patrick Williams. 2017. Critical Social Research as a 'Site of Resistance': Reflections on Relationships, Power and Positionality. Justice, Power and Resistance 1: 261-82.

Crewe, Ben, Alison Liebling, Nicola Padfield, and Graham Virgo. 2015. Joint Enterprise: the implications of an unfair and unclear law. Criminal Law Review 4: 252-69.

Garland, David. 1996. The Limits of the Sovereign State: Strategies of Crime Control in Contemporary Society. British Journal of Criminology 36: 445-71. [CrossRef]

Garland, D. 2001. The Culture of Control. Oxford: Oxford University Press.

Gilroy, Paul. 1982. The myth of black criminality. In Socialist Register. London: Merlin.

Gunnell, Daniel, Joseph Hillier, and Laura Blakeborough. 2016. Social Network Analysis of an Urban Street Gang Using Police Intelligence Data. London: Home Office.

Gutzmore, Cecil. 1983. Capital, 'black youth' and crime. Race and Class 25: 2. [CrossRef]

Haining, Robert, and Jane Law. 2007. Combining police perception with police records of serious crime records of serious crime areas: A modelling approach. Journal of the Royal Statistical Society Series A 170: 1019-34. [CrossRef]

Hall, Stuart, Charles Critcher, Tony Jefferson, and John Clarke. 1978. Policing the Crisis: Mugging, the State and Law and Order. London: Macmillan.

Hallsworth, Simon, and Tara Young. 2008. Gang talk and gang talkers: A critique. Crime Media Culture 4: 175-95. [CrossRef]

Harding, Simon. 2019. Trapped: Street Gangs, County Lines, and Exploitation. Bristol: Policy Press, Forthcoming.

Hillyard, Paddy, Christina Pantazis, Steve Tombs, and Dave Gordon, eds. 2004. Beyond Criminology: Taking Harm Seriously. London: Pluto Press.

HM Government. 2011. Ending Gangs and Youth Violence: A Cross Government Report; London: HMSO. Available online: www.gov.uk/government/uploads/system/uploads/attachment/data/file/97861/gang-violencesummary.pdf (accessed on 29 November 2013).

Home Office. 2007. Tackling Gangs Action Plan: A Practical Guide. Available online: http:/ /www.safecolleges. org.uk/sites/default/files/local_authorities.pdf (accessed on 11 November 2018).

Hulsman, Louk. 1986. Critical criminology and the concept of crime. Contemporary Crises 10: 63-80. [CrossRef]

Joseph, Ian, and James Gunter. 2011. What's a Gang and What's Race Got to Do with it? London: Runnymede Trust.

Katz, Jack, and Curtis Jackson-Jacobs. 2004. The criminologists gang. In The Blackwell Companion to Criminology. Edited by Colin Sumner. Oxford: Blackwell.

Keith, Michael. 1993. Race, Riots and Policing. London: UCL Press.

Krumer-Nevo, Michal, and Mirit Sidi. 2012. Writing Against Othering. Qualitative Inquiry 18: 299-309. [CrossRef] London Assembly Police and Crime Committee (LAPCC). 2016. Serious Youth Violence. Available online: https:// www.london.gov.uk/sites/default/files/serious_youth_violence_report_-_london_assembly.pdf (accessed on 25 January 2016). 
Lawrence, Errol. 2014. In the abundance of water the fool is thirsty: Sociology and black 'pathology' in CCCS 1982. In The Empire Strikes Back: Race and racism in 70s Britain. London: Hutchinson.

Lea, John, and Jock Young. 1984. What Is to Be Done about Law and Order: Crisis in the Eighties. Middlesex: Penguin Books.

Long, Rhiannon. 2018. Newham police chief: 'Things are horrific. Gangs are more dangerous than paedophiles'. New Recorder, March 29. Available online: https:/ / www.newhamrecorder.co.uk/news/crime-court/gangboys-have-it-coming-new-police-chief-for-newham-and-waltham-forest-promises-to-show-no-mercy-15453827 (accessed on 14 September 2018).

Ministry of Justice. 2017a. Statistics on Race and the Criminal Justice System 2016; London: UK Government.

Ministry of Justice. 2017b. An Independent Review into the Treatment of, and Outcomes for Black, Asian and Minority Ethnic Individuals in the Criminal Justice System. Available online: https:/ /www.gov.uk/ government/publications/lammy-review-final-report (accessed on 8 September 2017).

Moore, John. M. 2014. Is the Empire coming home? Liberalism, exclusion and the punitiveness of the British State. British Society of Criminology 14: 31-48.

Owusu-Bempah, Akwasi. 2017. Race and policing in historical context: Dehumanization and the policing of Black people in the 21st century. Theoretical Criminology 21. [CrossRef]

Phillips, Coretta, and Benjamin Bowling. 2003. Racism, ethnicity and criminology: Developing minority perspectives. British Journal of Criminology 43: 269-90. [CrossRef]

Pitts, John. 2007. Reluctant Gangsters. Cullumpton: Willan Publishing.

Scott, David. 2013. Rehumanising the Other and the meaning of Justice: An essay on the contribution of Barbara Hudson. European Group Newsletter, November.

Scott, Stafford. 2018. The War on Gangs or a Racialised War on Working Class Black Youths. London: The Monitoring Group.

Scraton, Phil, and Kathryn Chadwick. 1987. In the Arms of the Law: Coroners' Inquest and Deaths in Custody. London: Pluto Press.

Shiner, Michael, Zoe Carre, Rebekah Delsol, and Niamh Eastwood. 2018. The Numbers in Black and White 2.0: Ethnic Disparities in the Policing and Prosecution of Drug Offences in England and Wales. London: Stopwatch Charity. London: Stopwatch Charity.

Spalek, Basia. 2008. Communities, Identities and Crime. Bristol: The Policy Press.

Squires, Peter. 2016. Voodoo Liability: Joint Enterprise Prosecution as an Aspect of Intensified Criminalisation. Onati Socio-Legal Series 6: 937-56.

Stopwatch. 2018. Being Matrixed: The Over Policing of Gang Suspects in London. Available online: http: / / www.stop-watch.org/uploads/documents/Being_Matrixed.pdf (accessed on 19 September 2018).

Travis, Alan. 2011. UK Riots Analysis Reveals Gangs Did Not play Pivotal Role. Guardian, October 24. Available online: https:/ / www.theguardian.com/uk/2011/oct/24/riots-analysis-gangs-no-pivotal-role (accessed on 11 April 2018).

Tyler, Imogen. 2018. Resituating Goffman: From Stigma Power to Black Power. Unpublished paper. [CrossRef]

Williams, Patrick. 2015. Criminalising the Other: Challenging the Race and Gang nexus. Race and Class 56: 18-35. [CrossRef]

Williams, Patrick. 2017. Becoming (An)other: An Intergenerational Exploration of Storied Encounters of Migrations, Processes of Otherisation and Identity (re)Negotiations for Post-war Jamaican Families in Manchester, England. Ph.D. Thesis, University of Lancaster, Lancashire, UK.

Williams, Patrick, and Becky Clarke. 2016. Dangerous Associations: Joint Enterprise, Gangs and Racism. London: Centre for Crime and Justice Studies.

Williams, Patrick, and Becky Clarke. 2018. Disrupting the 'single story': Collective punishment, myth-making and the criminalisation of racialised communities. In Racism, Crime and Media. Edited by Monish Bhatia, Scott Poynting and Waqas Tufail. Basingstoke: Palgrave.

(C) 2018 by the authors. Licensee MDPI, Basel, Switzerland. This article is an open access article distributed under the terms and conditions of the Creative Commons Attribution (CC BY) license (http://creativecommons.org/licenses/by/4.0/). 